CENTRE for ECONOMIC

$\begin{array}{lllllllllll}P & E & R & F & O & M & A & N & C & E\end{array}$

CEP Discussion Paper No 1509

November 2017

\title{
Product Diversification in Indian Manufacturing
}

\author{
Johannes Boehm \\ Swati Dhingra \\ John Morrow
}




\begin{abstract}
The presence of global value chains challenges the neoclassical idea of the firm since it implies firms are not monolithic but are rather interdependent on the larger economic environment.

Examining establishments, the smallest units of production within firms, sheds light on the microeconomic incentives determining the location of production and whether a firm produces a good or sources it. Most work on multiproduct firms looks at developed countries, but constraints on firm growth are greater in developing economies. We examine multiproduct establishments in India during a high growth period. Multiproduct establishments made up the bulk of manufacturing production, and their product turnover contributed 28 per cent to net sales growth. Unlike the nineties which witnessed drastic liberalization, establishments in the two-thousands dropped products at rates similar to those for the US. Sales dispersion across products also predicts product addition.
\end{abstract}

Keywords: multiproduct firms, product adoption, product diversity

JEL: L1; L2; M2; O3

This paper was produced as part of the Centre's Trade Programme. The Centre for Economic Performance is financed by the Economic and Social Research Council.

We are grateful to Andy Bernard, Beata Javorcik, Kalina Manova, Keith Head, Veronica Rappoport and John Sutton for helpful comments as well as participants at Bilkent, CESIfo Venice, Warwick Trade Day, Oxford, LSE, RHUL, Sciences Po, SAET Cambridge and SED. We are indebted to Simen Gaure for help with the R package lfe. Boehm thanks the Sciences Po - Banque de France partnership for financial assistance, Dhingra thanks the ERC Starting Grant 760037 for funding, and Morrow thanks the LSE - TISS - TATA Grant for financial assistance. Yan Liang provided excellent research assistance.

Johannes Boehm, Sciences Po and Princeton. Swati Dhingra, London School of Economics, Centre for Economic Performance, CEPR and CESifo. John Morrow, Birkbeck, Centre for Economic Performance, London School of Economics and CEPR.

Published by

Centre for Economic Performance

London School of Economics and Political Science

Houghton Street

London WC2A 2AE

All rights reserved. No part of this publication may be reproduced, stored in a retrieval system or transmitted in any form or by any means without the prior permission in writing of the publisher nor be issued to the public or circulated in any form other than that in which it is published.

Requests for permission to reproduce any article or part of the Working Paper should be sent to the editor at the above address.

J. Boehm, S. Dhingra and J. Morrow, submitted 2017. 


\section{INTRODUCTION}

The presence of global value chains challenges the neoclassical idea of the firm since it implies firms are not monolithic but rather choose both where to locate production and also whether to produce inputs and outputs within their boundary. Furthermore, firms tend to co-produce products, making them multiproduct firms, and these firms dominate production and trade. ${ }^{1}$ Understanding how the smallest units of production within firms make production choices, i.e. how establishments within firms adapt their product mix to adjust to their economic environment, sheds light on the microeconomic incentives determining the location of production and whether a firm produces a good or sources it.

The question of why firms make several products within one plant has a long tradition in industrial organization and business economics. In influential work on the theory of the firm, Penrose (1955) proposes that successful product diversification enables firms to avoid the limits to growth imposed by the size of a single product market. Firms make investments to reorient their product mix, and these activities make up a large fraction of aggregate changes in industry-level variety and productivity. ${ }^{2}$ Adding or dropping a product is an important event for firms. A growing literature shows firms tend to move towards a few successful products, and focusing on these selected products enables them to survive and grow (Bernard et al. 2010b, 2011; Eckel and Neary 2010; Eckel et al. 2009; Mayer et al. 2009; Iacovone and Javorcik 2010).

However, we know little about the process of product diversification in developing economies. Studying the period just after the liberalization of 1991, Goldberg et al. examine product turnover of manufacturing firms in India, and show that multiproduct firms engage in substantial product adjustment. A striking finding is that the input tariff reductions of the nineties enabled Indian firms to increase their product range, but these firms engaged in very little product dropping, relative to their US counterparts. Goldberg et al. suggest that this might be due to remnants of the licensing regime that make it difficult to drop unprofitable products or due to the rapid growth in the post-liberalization era. ${ }^{3}$

We examine product turnover of manufacturing establishments in India during the early 2000s. This is a period of high growth, much higher than the post-liberalization period of the nineties. Bollard et al. (2013) find that only a small fraction of this high growth can be attributed to policy reforms such as tariff cuts, investment policies and delicensing

\footnotetext{
${ }^{1}$ In the United States, 90 per cent of manufacturing production is done by multiproduct firms, and 89 per cent of these firms adjusted their product mix within five years (Bernard et al. 2010a).

${ }^{2}$ For example, Bernard et al. (2010b) find that within-firm product expansion accounts for about half of US output of new products. Doraszelski and Jaumandreu (2007) show within-firm productivity growth accounts for two-thirds of total productivity gains among Spanish firms.

${ }^{3}$ This is important because constraints on firm growth are particularly acute in developing countries (The World Bank 2013). Firms in developing countries are typically smaller, less productive and grow less, relative to firms in developed countries (Bloom et al. 2010).
} 
of products. Most of the unaccounted productivity growth is within firms, and mainly concentrated in large firms (Harrison et al. 2013). Using detailed survey data, we document the product turnover patterns of Indian firms. We find that multiproduct firms made up the bulk of manufacturing production, and their product turnover contributed 28 percent to net sales growth. Unlike the nineties, firms dropped products at rates similar to those for US firms. We therefore capture the process of product turnover of firms in a developing economy that moved from severe constraints on product rationalization to a more dynamic environment. We also find that higher sales dispersion across products predicts product addition.

The remainder of the paper starts with a description of the Indian plant data in Section 2. Section 3 contains the basic patterns and compares it with those for the United States and India during the nineties. Section 4 concludes.

\section{Indian Manufacturing Data}

We use annual data on manufacturing firms from the Indian Annual Survey of Industry (ASI), which is conducted by the Indian Ministry of Statistics and Programme Implementation, and is the Indian government's main source of industrial statistics on the formal manufacturing sector.

The ASI consists of two parts: a census of all manufacturing plants that are larger than 100 employees, and a random sample of one fifth of all plants that employ between 20 and 100 workers. The ASI's sampling methodology and product classifications have changed several times over the course of its history. In order to ensure consistency, we focus on the time frame of the fiscal years (May to April) 2000/01 to 2007/08.

The ASI contains information on outputs at the plant level. It differs from the Prowess database, published by the Centre for Monitoring the Indian Economy and used by Goldberg et al. (2009) (henceforth GKPT) to document product turnover among Indian manufacturing firms. Compared to the ASI, the Prowess database contains only information on firms listed on the Bombay Stock Exchange.

The key variable for our analysis is the product turnover of firms. So the product definitions of the ASI and their comparison with other studies is important. The pioneering study of multiproduct firms is Bernard et al. (2010b) (henceforth BRS) which documents multiproduct manufacturing firms in the United States using the US Census Bureau's Longitudinal Business Database. At their finest level, BRS have 1,440 5-digit SIC products for US firms in 455 4-digit industries belonging to 20 2-digit SIC sectors. GKPT have 1,886 "products" under 108 4-digit NIC industries in 22 2-digit NIC sectors. Compared to them, ASI has 5,204 5-digit ASIC products at the finest level. A broader 4-digit code contains 1,108 distinct products which is roughly comparable (in the numbers of product codes) with 
the finest levels reported in BRS and GKPT. These products are in 262 3-digit ASIC industries, which can be further aggregated to 64 2-digit sectors or nine 1-digit sectors. Table 1 summarizes alternative definitions for products and classification codes in each database.

Table 1. Product Definitions

\begin{tabular}{lrrr}
\hline Number of: & BRS & GKPT & ASI \\
\hline Finest Products & 1,440 5-digit SIC & 1,886 CMIE & 5,204 5-digit; 1,108 4-digit \\
Finer Products & 455 4-digit SIC & 108 4-digit NIC & 262 3-digit ASIC \\
Sectors & 20 2-digit SIC & 22 2-digit NIC & 64 2-digit/9 1-digit \\
\hline Classification & 5/4-digit SIC & CMIE/4-digit NIC & 5/4/3/2/1-digit ASIC \\
\hline
\end{tabular}

\section{Product Turnover Among Indian Manufacturing Firms}

This section describes the nature of product turnover in multiproduct Indian firms during the 2000s. Five key facts emerge:

(1) Multi-product firms dominate production.

(2) Firms focus on core competencies.

(3) Product turnover is prevalent.

(4) Product churning is similar to the US.

(5) Higher sales dispersion across products predicts product addition.

This section examines each of these in turn.

3.1. Multi-Product Firms Dominate Production. Table 2 shows the prevalence of multi-product firms in our sample. Multi-product firms account for 39\% of observations at the 4-digit level (41\% if products are defined at the 5-digit level), similar to BRS and GKPT's datasets (39\% and 47\%, respectively). As is well known, multi-product firms tend to be larger: they account for $71 \%$ of sales. Multi-sector firms account for $19 \%$ (2-digit) and $8 \%$ (1-digit) of the observations in the sample, but $49 \%$ (32\% respectively) of sales. 
Table 2. Frequency and Sales Shares of Firms

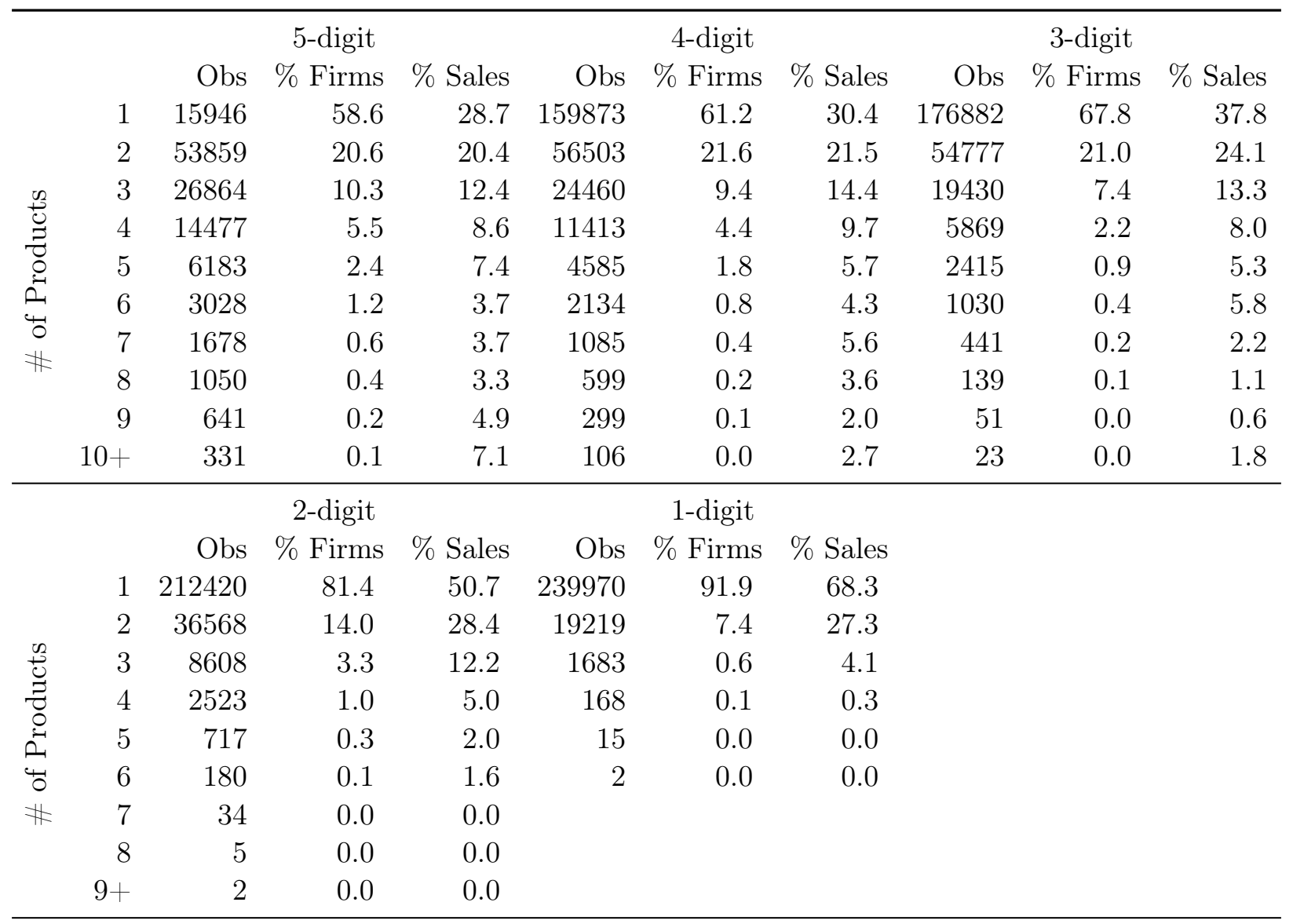

Source: Author's calculations from ASI data.

GKPT's sample of publicly listed firms in India during the nineties gives similar results, $24 \%$ of firms are multi-sector firms and their share in total sales is $54 \%$. Table 3 compares sales shares in our sample with GKPT.

Table 3. Comparison of Multiproduct Firms in GKPT and ASI

\begin{tabular}{lcccccccc}
\hline & \multicolumn{3}{c}{ Share of Firms } & & \multicolumn{2}{c}{ Share of Output } & & \multicolumn{2}{c}{ Mean \#Products } \\
\cline { 2 - 3 } Type of Firm & ASI & GKPT & & ASI & GKPT & & ASI & GKPT \\
\hline Multiple 4-digit Products & 0.39 & 0.47 & & 0.70 & 0.80 & & 2.81 & 3.06 \\
Multiple 3-digit Products & 0.22 & 0.33 & & 0.62 & 0.62 & & 2.55 & 2.01 \\
Multiple 2-digit Products & 0.19 & 0.24 & & 0.49 & 0.54 & & 2.34 & 1.68 \\
\hline
\end{tabular}

Note: 'Mean \#Products' refers to the average number of products in the respective subsample.

Products are based on ASIC in ASI and CMIE/NIC in GKPT.

3.2. Firms Focus on Their Core Competencies. Table 4 shows the sales distribution of products within firms. The fact that a firm generates a large proportion of its sales revenue 
from its primary products suggests that firms have 'core competencies'. The concentration of sales is similar to the findings of GKPT (Table 3) that uses the CMIE data on publicly listed firms. This confirms the soundness of the data and the comparability across the datasets. ${ }^{4}$

Table 4. Average Sales Shares by Product Rank

\begin{tabular}{|c|c|c|c|c|c|c|c|c|c|c|c|c|c|c|c|c|c|c|c|c|c|}
\hline \multirow[b]{2}{*}{ Rank } & \multicolumn{10}{|c|}{ 4-digit Products in ASI } & \multicolumn{11}{|c|}{ GKPT 4-digit Products } \\
\hline & 1 & 2 & 3 & 4 & 5 & 6 & 7 & 8 & 9 & 10 & Rank & 1 & 2 & 3 & 4 & 5 & 6 & 7 & 8 & 9 & $10+$ \\
\hline 1 & 100 & 87 & 78 & 72 & 62 & 57 & 54 & 51 & 46 & 44 & 1 & 100 & 86 & 75 & 70 & 65 & 63 & 62 & 64 & 53 & 44 \\
\hline 2 & & 13 & 17 & 18 & 21 & 22 & 22 & 20 & 20 & 20 & 2 & & 14 & 20 & 21 & 21 & 21 & 19 & 16 & 22 & 20 \\
\hline 3 & & & 5 & 7 & 10 & 11 & 11 & 12 & 12 & 11 & 3 & & & 4 & 7 & 9 & 9 & 9 & 9 & 12 & 13 \\
\hline 4 & & & & 2 & 5 & 6 & 64 & 7 & 8 & 8 & 4 & & & & 2 & 4 & 4 & 6 & 5 & 7 & 7 \\
\hline 5 & & & & & 2 & 3 & 4 & 5 & 5 & 6 & 5 & & & & & 2 & 2 & 3 & 3 & 3 & 4 \\
\hline 6 & & & & & & 1 & 2 & 3 & 4 & 4 & 6 & & & & & & 1 & 1 & 2 & 2 & 3 \\
\hline 7 & & & & & & & 1 & 2 & 3 & 3 & 7 & & & & & & & 0 & 1 & 1 & 2 \\
\hline 8 & & & & & & & & 1 & 2 & 2 & 8 & & & & & & & & 0 & 1 & 2 \\
\hline 9 & & & & & & & & & 1 & 1 & 9 & & & & & & & & & 0 & 1 \\
\hline $10+$ & & & & & & & & & & 1 & & & & & & & & & & & 2 \\
\hline
\end{tabular}

Note: Columns indicate the number of products, rows indicate the sales rank of the product.

3.3. Product Turnover is Prevalent. We now turn to documenting product turnover among the ASI firms. To study the determinants of product turnover, we will examine how firms add products across different ASIC industries. Table 5 shows the fraction of firms that change their product scope over a one-year, three-year, and five-year horizon. Given the nature of the ASI sampling methodology, our panel is not balanced; an $n$-year horizon hence consists of all observation pairs that are $n$ years apart from each other. The product scope changes are forward-looking: a plant that produces one product in year $t$ and the same product together with a new one in year $t+1$ would be counted as an 'add only' for a single-product firm at the one-year horizon. Looking at the 4-digit ASIC category, we find that $65 \%$ of all firms make some change in their product range in a 5-year horizon. The corresponding number for 3 -digit products is $57 \%$, showing that product churning is highly prevalent. This product churning (at the 4-digit level) makes up $28 \%$ of the net sales growth per year for manufacturing during 2002-2008. ${ }^{5}$

\footnotetext{
${ }^{4}$ We are unable to replicate GKPT for the nineties using the ASI because it does not have a panel dimension in the nineties.

${ }^{5}$ Numbers in the table are the percentage of firm-year observations that fall in the respective category. Product additions and drops are defined forward-looking, i.e. if a firm has one product in year 2001, and sells the same product plus an additional one in year 2002, this would count as one observation in the "add only" category in 2001 (also, it would count as a single-product firm). Hence, by definition, single-product firms cannot only drop a product.
} 
Table 5. Product Turnover

\begin{tabular}{|c|c|c|c|c|c|c|c|c|c|c|c|c|c|c|c|c|c|c|c|c|c|c|c|c|c|}
\hline & & \multicolumn{12}{|c|}{ Percentage of Firms } & \multicolumn{12}{|c|}{ Sales-Weighted Percentage of Firms } \\
\hline & & \multicolumn{4}{|c|}{ 1-year Horizon } & \multicolumn{4}{|c|}{ 3-year Horizon } & \multicolumn{4}{|c|}{ 5-year Horizon } & \multicolumn{4}{|c|}{ 1-year Horizon } & \multicolumn{4}{|c|}{ 3-year Horizon } & \multicolumn{4}{|c|}{ 5-year Horizon } \\
\hline & & 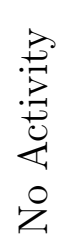 & $\begin{array}{l}\overrightarrow{3} \\
0 \\
0 \\
\overrightarrow{0} \\
\frac{0}{4}\end{array}$ & 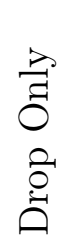 & 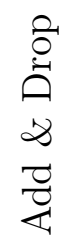 & 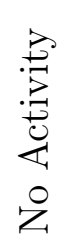 & $\begin{array}{l}\overrightarrow{3} \\
0 \\
\overrightarrow{0} \\
\frac{0}{4}\end{array}$ & $\begin{array}{l}\overrightarrow{\vec{J}} \\
0 \\
\tilde{0} \\
\dot{0}\end{array}$ & 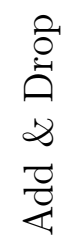 & 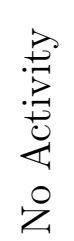 & $\begin{array}{l}\vec{\partial} \\
\overrightarrow{0} \\
\overrightarrow{0} \\
\frac{\vec{Z}}{4}\end{array}$ & $\begin{array}{l}\vec{\Xi} \\
0 \\
0 \\
0 \\
\dot{0}\end{array}$ & 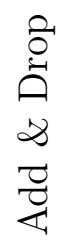 & 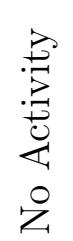 & $\begin{array}{l}\vec{z} \\
\overrightarrow{0} \\
\frac{0}{2} \\
\frac{\vec{Z}}{4}\end{array}$ & 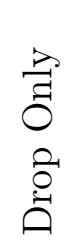 & 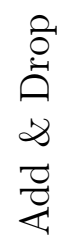 & 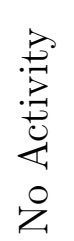 & $\begin{array}{l}\vec{z} \\
\overrightarrow{0} \\
\overrightarrow{0} \\
\frac{\vec{Z}}{4}\end{array}$ & 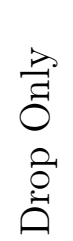 & $\begin{array}{l}\stackrel{2}{0} \\
\dot{0} \\
\dot{D} \\
\overrightarrow{0} \\
\ddot{Z}\end{array}$ & 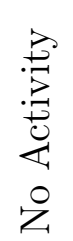 & $\begin{array}{l}\overrightarrow{3} \\
0 \\
\overrightarrow{0} \\
\vec{Z}\end{array}$ & $\begin{array}{l}\vec{\exists} \\
0 \\
0 \\
0 \\
0 \\
0\end{array}$ & 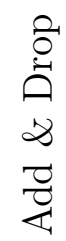 \\
\hline \multirow{3}{*}{ 1-digit } & Single & 93 & 4 & & 3 & 92 & 5 & & 4 & 91 & 5 & & 4 & 93 & 6 & & 1 & 92 & 7 & & 1 & 91 & 7 & & 1 \\
\hline & Multi & 51 & 4 & 38 & 7 & 40 & 4 & 48 & 8 & 34 & 3 & 53 & 9 & 59 & 5 & 25 & 11 & 58 & 5 & 30 & 7 & 56 & 4 & 36 & 4 \\
\hline & All & 89 & 4 & 4 & 4 & 86 & 4 & 5 & 4 & 85 & 5 & 6 & 5 & 81 & 5 & 9 & 5 & 80 & 6 & 10 & 3 & 80 & 6 & 12 & 2 \\
\hline \multirow{3}{*}{ 2-digit } & Single & 84 & 7 & & 10 & 81 & 8 & & 11 & 79 & 9 & & 12 & 89 & 7 & & 4 & 89 & 7 & & 4 & 89 & 7 & & 4 \\
\hline & Multi & 41 & 7 & 31 & 21 & 30 & 7 & 38 & 24 & 26 & 7 & 42 & 25 & 41 & 9 & 27 & 23 & 35 & 10 & 34 & 22 & 35 & 6 & 40 & 19 \\
\hline & All & 74 & 7 & 7 & 12 & 69 & 8 & 9 & 14 & 66 & 9 & 11 & 15 & 64 & 8 & 14 & 14 & 61 & 8 & 18 & 13 & 62 & 6 & 20 & 12 \\
\hline \multirow{3}{*}{ 3-digit } & Single & 75 & 8 & & 17 & 70 & 11 & & 19 & 68 & 12 & & 20 & 86 & 7 & & 7 & 85 & 8 & & 7 & 84 & 8 & & 8 \\
\hline & Multi & 36 & 8 & 24 & 33 & 26 & 8 & 29 & 36 & 22 & 8 & 31 & 39 & 29 & 10 & 25 & 37 & 23 & 14 & 26 & 38 & 22 & 9 & 34 & 36 \\
\hline & All & 62 & 8 & 8 & 22 & 54 & 10 & 11 & 25 & 51 & 10 & 12 & 27 & 48 & 9 & 16 & 27 & 44 & 12 & 17 & 27 & 43 & 9 & 22 & 26 \\
\hline \multirow{3}{*}{ 4-digit } & Single & 63 & 7 & & 30 & 56 & 10 & & 35 & 52 & 11 & & 37 & 80 & 5 & & 15 & 79 & 6 & & 15 & 77 & 7 & & 16 \\
\hline & Multi & 26 & 6 & 16 & 51 & 18 & 7 & 20 & 56 & 15 & 6 & 21 & 58 & 23 & 6 & 17 & 54 & 16 & 11 & 17 & 56 & 15 & 6 & 20 & 59 \\
\hline & All & 47 & 7 & 7 & 39 & 39 & 8 & 9 & 44 & 35 & 9 & 10 & 47 & 39 & 5 & 12 & 44 & 33 & 10 & 12 & 45 & 32 & 6 & 15 & 47 \\
\hline
\end{tabular}


3.4. Product Churning Rates are Similar to US Firms. One fact that emerges is that product turnover in the ASI data is broadly similar to BRS. Looking at the comparable 4-digit ASIC category, we find that $65 \%$ of all firms make some change in their product range in a 5 -year horizon, compared to $54 \%$ of firms in BRS. For multi-product firms, this difference is smaller: $85 \%$ in the ASI data compared with $80 \%$ in BRS. The main difference is a higher percentage of multiproduct firms drop products in the ASI than BRS, but this difference is small when the prevalence is weighted by firm sales. Compared to BRS, we find that fewer firms add and drop products, leading to higher levels of no activity firms when weighted by firm sales.

Another fact that emerges is that product turnover in the ASI data is higher than in GKPT. Even looking at the highly aggregate 2-digit ASIC category (which has 64 product categories), we find that $26 \%$ of all firms make some change in their product range. GKPT find instead that only $10 \%$ of firms engage in product range changes where the product is the finest level of aggregation which has 1,500 product categories. For multi-product firms, this difference is even wider: $59 \%$ in the ASI data compared with $14 \%$ in GKPT. These differences are also present for both the subset of sample firms of the ASI and the subset of census ASI firms. Compared to GKPT, we also find higher levels of product dropping. In our sample, 7 percent of all firms drop products (4-digit) without adding new ones in the same year. The figure is higher over a three-year horizon (9\%) and five-year horizon (10\%). In GKPT's sample, only 2\% of firms drop products without adding new ones (3\% and 5\% over a three-year and five-year horizon). The right panel of Table 6 weighs the fractions of product-changing firms by their sales revenue. Twelve percent of sales revenue gets dropped at an annual frequency without being replaced by a new product in the same period (in GKPT's sample, the corresponding fraction is three percent). ${ }^{6}$

\footnotetext{
${ }^{6}$ The fact that many firms seem to be replacing existing products by new ones raises concerns about the quality of the reported product codes. If plant managers are inconsistent over time in their reporting of product codes, the true fraction of firms that is either adding or dropping products would be higher than the observed fraction of firms. Hence, our estimates of the prevalence of product additions or droppings are lower bounds for the true number. Note also that misreporting of product codes is likely to be washed out as we aggregate products to three-digit industries and one- or two-digit sectors.
} 
Table 6. Product Turnover Over A Five-Year Horizon

\begin{tabular}{|c|c|c|c|c|c|c|c|c|c|}
\hline & & \multicolumn{4}{|c|}{$\%$ of Firms } & \multicolumn{4}{|c|}{ Sales-wtd. \% of Firms } \\
\hline & & & Add & Drop & Add \& & & Add & Drop & Add \& \\
\hline & & Activity & Only & Only & Drop & Activity & Only & Only & Drop \\
\hline \multirow{3}{*}{ 4-digit } & Single & 52 & 11 & & 37 & 77 & 7 & & 16 \\
\hline & Multi & 15 & 6 & 21 & 58 & 15 & 6 & 20 & 59 \\
\hline & All & 35 & 9 & 10 & 47 & 32 & 6 & 15 & 47 \\
\hline \multirow{3}{*}{ GKPT } & Single & 80 & 19 & & 1 & 76 & 24 & & 0 \\
\hline & Multi & 63 & 26 & 8 & 3 & 53 & 29 & 3 & 15 \\
\hline & All & 72 & 22 & 4 & 2 & 57 & 28 & 2 & 12 \\
\hline \multirow{3}{*}{$\mathrm{BRS}$} & Single & & & & & & & & \\
\hline & Multi & 20 & 32 & 12 & 36 & 6 & 12 & 8 & 75 \\
\hline & All & 46 & 14 & 15 & 25 & 11 & 10 & 10 & 68 \\
\hline
\end{tabular}

Note: Numbers in the table are the percentage of firm-year observations that fall in the respective category. Product additions and drops are defined forward-looking, i.e. if a firm has one product in year 2001, and sells the same product plus an additional one in year 2002, this would count as one observation in the "add only" category in 2001 (also, it would count as a single-product firm). Hence, by definition, single-product firms cannot only drop a product. Rows "BRS" are reproduced from Table 3 in Bernard et al. (2010a). Rows "GKPT" are reproduced from Table 4 in Goldberg et al. (2009).

Perhaps the most striking difference between our results and GKPT's is the prevalence of product droppings by multi-product firms. In Table 7 we decompose product scope changes by studying the transition matrix of the number of products. Element $(n, k)$ is the number (top panel) or percentage (lower panel) of firm-year observation with $n$ products that have $k$ products the next time we observe them. The matrix in the top panel looks fairly symmetric, suggesting that there is no salient trend in the average number of products in our sample. Since the distribution is skewed towards firms with fewer products, the transition probabilities are higher for a reduction in the number of products, which also explains the high probability of product droppings among multi-product firms in Table 5. 
PRODUCT DIVERSIFICATION IN INDIAN MANUFACTURING

Table 7. Transition Matrix for the Number of Products

\begin{tabular}{|c|c|c|c|c|c|c|c|c|c|c|c|c|}
\hline \multicolumn{13}{|c|}{ A. Number of Observations } \\
\hline \multirow{13}{*}{ 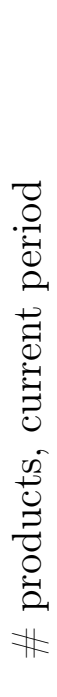 } & & \multicolumn{11}{|c|}{ \# products, next time we observe the firm } \\
\hline & & 1 & 2 & 3 & 4 & 5 & 6 & 7 & 8 & 9 & 10 & $11+$ \\
\hline & 1 & 76023 & 7817 & 1688 & 528 & 209 & 92 & 35 & 18 & 8 & 3 & 0 \\
\hline & 2 & 7810 & 19402 & 3766 & 897 & 260 & 78 & 31 & 10 & 5 & 2 & 1 \\
\hline & 3 & 1767 & 3597 & 6790 & 1720 & 451 & 133 & 51 & 17 & 12 & 3 & 1 \\
\hline & 4 & 597 & 865 & 1762 & 2890 & 697 & 206 & 63 & 26 & 8 & 5 & 0 \\
\hline & 5 & 257 & 244 & 441 & 696 & 917 & 334 & 114 & 51 & 13 & 8 & 0 \\
\hline & 6 & 107 & 77 & 142 & 224 & 312 & 338 & 142 & 55 & 21 & 4 & 1 \\
\hline & 7 & 46 & 43 & 49 & 75 & 107 & 143 & 162 & 83 & 27 & 6 & 4 \\
\hline & 8 & 41 & 16 & 19 & 22 & 38 & 62 & 91 & 99 & 40 & 7 & 1 \\
\hline & 9 & 13 & 3 & 6 & 8 & 14 & 26 & 33 & 44 & 53 & 13 & 3 \\
\hline & 10 & 2 & 1 & 2 & 8 & 3 & 4 & 7 & 8 & 11 & 8 & 2 \\
\hline & $11+$ & 0 & 0 & 0 & 1 & 0 & 2 & 4 & 0 & 1 & 1 & 8 \\
\hline \multicolumn{13}{|c|}{ B. Transition Probabilities } \\
\hline \multicolumn{13}{|c|}{ \# products, next time we observe the firm } \\
\hline \multirow{12}{*}{ 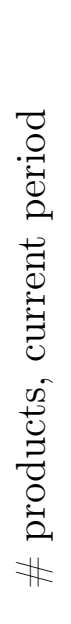 } & & 1 & 2 & 3 & 4 & 5 & 6 & 7 & 8 & 9 & 10 & $11+$ \\
\hline & 1 & 88 & 9 & 2 & 1 & 0 & 0 & 0 & 0 & 0 & 0 & 0 \\
\hline & 2 & 24 & 60 & 12 & 3 & 1 & 0 & 0 & 0 & 0 & 0 & 0 \\
\hline & 3 & 12 & 25 & 47 & 12 & 3 & 1 & 0 & 0 & 0 & 0 & 0 \\
\hline & 4 & 8 & 12 & 25 & 41 & 10 & 3 & 1 & 0 & 0 & 0 & 0 \\
\hline & 5 & 8 & 8 & 14 & 23 & 30 & 11 & 4 & 2 & 0 & 0 & 0 \\
\hline & 6 & 8 & 5 & 10 & 16 & 22 & 24 & 10 & 4 & 1 & 0 & 0 \\
\hline & 7 & 6 & 6 & 7 & 10 & 14 & 19 & 22 & 11 & 4 & 1 & 1 \\
\hline & 8 & 9 & 4 & 4 & 5 & 9 & 14 & 21 & 23 & 9 & 2 & 0 \\
\hline & 9 & 6 & 1 & 3 & 4 & 6 & 12 & 15 & 20 & 25 & 6 & 1 \\
\hline & 10 & 4 & 2 & 4 & 14 & 5 & 7 & 13 & 14 & 20 & 14 & 4 \\
\hline & $11+$ & 0 & 0 & 0 & 6 & 0 & 12 & 24 & 0 & 6 & 6 & 47 \\
\hline
\end{tabular}

Note: Products are defined at the 4-digit ASIC level. 
3.5. Firms with more sales dispersion are more likely to add products. We now turn to investigating the relationship between the diversification of a firm across product lines and product turnover. We use the specification

$$
\mathrm{CHANGE}_{j t}=\beta \mathrm{CONC}_{j t}+\delta \mathrm{NUMPROD}_{j t}+\gamma \mathrm{CTRL}_{j t}+\alpha_{j}+\alpha_{t}+\varepsilon_{j t}
$$

The dependent variable $\mathrm{CHANGE}_{j t}$ either encapsulates product additions or drops, depending on the econometric specification. In the case of product additions, $\mathrm{CHANGE}_{j t}$ is one if firm $j$ adds a 4-digit product between year $t$ and $t+1$ (similarly for product drops). The explanatory variables are as follows:

- $\mathrm{CONC}_{j t}$ is a Herfindahl-Hirschman concentration index of sales among the set of a firm's products, $I_{j t}$, defined as

$$
\mathrm{CONC}_{j t}=\sum_{i \in I_{j t}} s_{j i t}^{2}
$$

where $s_{j i t}$ is firm $j$ 's share of sales coming from product $i$. $\mathrm{CONC}_{j t}$ close to one means that almost all the sales revenue is coming from a single product; if the revenue coming from the different products is equal, the index takes its minimum of $1 /\left|I_{j t}\right|$ where $\left|I_{j t}\right|$ is the number of products made by the firm.

- $\mathrm{NUMPROD}_{j t}$ is a vector of zero-one indicator variables for the number of products (up to 50$)$.

- $\mathrm{CTRL}_{j t}$ is a vector of firm-year specific controls, such as size and age.

- $\alpha_{j}$ and $\alpha_{t}$ are firm and year fixed effects.

By estimating Equation (3.1), we are studying the correlation between product turnover and sales concentration, conditional on firm characteristics. While it is true that firms with fewer products will typically have higher concentration of sales as measured by the Herfindahl index $\mathrm{CONC}_{j t}$, we are explicitly taking out the effect of the number of products on turnover by including a set product add or drop rates by the current number of firm products. Hence, the coefficient $\beta$ in equation (3.1) is the conditional correlation of concentration and product turnover both within the firm (over time) and within a group of firms that have the same number of products. In order to avoid spurious results due to potential misclassification of products, we only consider product additions and droppings where the rest of the product range remains unchanged ('add only' and 'drop only' in Table 5).

Table 8 shows the results from estimating equation (3.1) using ordinary least squares. With a product drop dummy as a dependent variable, the coefficient of the sales concentration index is positive and statistically significant: a higher concentration of sales is positively correlated with the firm dropping a product. Quantitatively, a one standard deviation increase is associated with a 1.9-3.5\% increase in the probability of the firm dropping one or more products. Similarly, with a product addition dummy as the dependent variable (columns 5 
and 6 of Table 8), the coefficient of the sales concentration index is negative and significant. Hence, firms that see an increase in their sales concentration index are more likely to drop, and less likely to add a product.

Table 8. Concentration and Product Turnover

\begin{tabular}{|c|c|c|c|c|c|c|}
\hline & \multicolumn{4}{|c|}{ Dependent variable: Product Drop Indicator } & \multicolumn{2}{|c|}{ Product Add Indicator } \\
\hline & $(1)$ & $(2)$ & $(3)$ & $(4)$ & $(5)$ & $(6)$ \\
\hline$C O N C_{j t}$ & $\begin{array}{l}0.101^{* * *} \\
(0.00825)\end{array}$ & $\begin{array}{c}0.114^{* * *} \\
(0.0128)\end{array}$ & $\begin{array}{c}0.166^{* * *} \\
(0.0190)\end{array}$ & $\begin{array}{c}0.182^{* * *} \\
(0.0323)\end{array}$ & $\begin{array}{c}-0.127^{* * * *} \\
(0.0163)\end{array}$ & $\begin{array}{c}-0.114^{* * * *} \\
(0.0221)\end{array}$ \\
\hline Firm Age & $\begin{array}{c}-0.00182^{* *} \\
(0.000689)\end{array}$ & $\begin{array}{r}-0.00438^{*} \\
(0.00173)\end{array}$ & & & & \\
\hline Log Firm Size & $\begin{array}{c}-0.00588^{* * *} \\
(0.000739)\end{array}$ & $\begin{array}{c}-0.0141^{* * *} \\
(0.00178)\end{array}$ & $\begin{array}{c}-0.0105^{* *} \\
(0.00380)\end{array}$ & $\begin{array}{c}-0.0223^{*} \\
(0.0102)\end{array}$ & $\begin{array}{c}0.00353 \\
(0.00326)\end{array}$ & $\begin{array}{c}0.0133 \\
(0.00694)\end{array}$ \\
\hline \# products dummies & yes & yes & yes & yes & yes & yes \\
\hline Year FE & yes & yes & yes & yes & yes & yes \\
\hline Firm FE & & & yes & yes & yes & yes \\
\hline Sample & Full & Multi-product & Full & Multi-product & Full & Multi-product \\
\hline $\mathrm{N}$ & 66822 & 28283 & 66822 & 28283 & 66822 & 28283 \\
\hline R-sq & 0.131 & 0.012 & 0.664 & 0.661 & 0.560 & 0.515 \\
\hline
\end{tabular}

\section{Conclusion}

Firms' product scope and turnover are an important component of the organization of economic activity within firms, their microeconomic responses and their contribution to aggregate growth. Our paper has investigated product turnover in a large developing country in which multi-product firms dominate production. While previous work has suggested that product turnover in India have been lower because of its history of licensing constraints, we instead find high product turnover rates that are comparable to the United States in the recent post-liberalization period. Furthermore, we find a key determinant production churning is sales dispersion: firms with less concentrated product lines add more products and drop fewer products, controlling for the number of products. Whether these product dynamic patterns generalize to other settings remains to be seen, but they suggest a rich area of further study for both microeconomic theories of the firm and sources of aggregate growth.

\section{REFERENCES}

Bernard, A. B., S. J. Redding, And P. K. Schott (2010a): "Multiple-Product Firms and Product Switching," American Economic Review, 100, 70-97. 
(2010b): "Multiple-Product Firms and Product Switching," The American Economic Review, 100, 70-97.

(2011): "Multiproduct Firms and Trade Liberalization," The Quarterly Journal of Economics, 126, 1271-1318.

Bloom, N., A. Mahajan, D. McKenzie, And J. Roberts (2010): "Why Do Firms in Developing Countries Have Low Productivity?" The American Economic Review, 619623.

Bollard, A., P. J. Klenow, and G. Sharma (2013): "India's Mysterious Manufacturing Miracle," Review of Economic Dynamics, 16, 59-85.

Doraszelski, U. And J. Jaumandreu (2007): "R\&D and Productivity: Estimating Production Functions when Productivity is Endogenous," Documentos de trabajo. Economic series (Universidad Carlos III. Departamento de Economia), 1.

Eckel, C., L. Iacovone, B. S. Javorcik, And P. Neary (2009): "Multi-product Firms at Home and Away," Tech. rep., Mimeo.

ECKEL, C. AND P. NeARY (2010): "Multi-product Firms and Flexible Manufacturing in the Global Economy," Review of Economic Studies, 77, 188-217.

Gaure, S. (2013): "Ife: Linear Group Fixed Effects," The R Journal, 5, 104-117.

Goldberg, P. K., A. K. Khandelwal, N. Pavcnik, and P. Topalova (2009): "Multiproduct Firms and Product Turnover in the Developing World: Evidence from India," The Review of Economics and Statistics.

Harrison, A. E., L. A. Martin, And S. Nataraj (2013): "Learning versus Stealing: How Important Are Market-Share Reallocations to India's Productivity Growth?" The World Bank Economic Review, 27, 202-228.

IACOvone, L. And B. S. JavorciK (2010): "Multi-Product Exporters: Product Churning, Uncertainty and Export Discoveries," The Economic Journal, 120, 481-499.

Mayer, T., M. J. Melitz, and G. I. P. Ottaviano (2009): "Market size, Competition, and the Product Mix of Exporters," Working Paper.

Penrose, E. (1955): "Limits to the Growth and Size of Firms," The American Economic Review, 531-543.

The World Bank (2013): Global Economic Prospects, vol. 7, World Bank Publications. 


\section{CENTRE FOR ECONOMIC PERFORMANCE \\ Recent Discussion Papers}

1508 Hanwei Huang

Jiandong Ju

Vivian Z. Yue

1507 Laura Alfaro

Pol Antràs

Davin Chor

Paolo Conconi

1506 Alessandro Iaria

Carlo Schwarz

Fabian Waldinger

1505 Fabrice Defever

Alejandro Riaño

1504 Gene M. Grossman

Elhanan Helpman

Ezra Oberfield

Thomas Sampson

1503 Camille Landais

Arash Nekoei

Peter Nilsson

David Seim

Johannes Spinnewijn

1502 Swati Dhingra

John Morrow

1501 Richard Murphy

Judith Scott-Clayton

Gill Wyness

1500 Nicholas Bloom

Renata Lemos

Raffaella Sadun

John Van Reenen

1499 Thomas Sampson
Structural Adjustments and International

Trade: Theory and Evidence from China

Internalizing Global Value Chains:

A Firm-Level Analysis

Frontier Knowledge and Scientific

Production: Evidence from the Collapse of International Science

Twin Peaks

The Productivity Slowdown and the Declining Labor Share: A Neoclassical Exploration

Risk-Based Selection in Unemployment Insurance: Evidence and Implications

Efficiency in Large Markets with Firm Heterogeneity

The End of Free College in England:

Implications for Quality, Enrolments and Equity

Healthy Business? Managerial Education and Management in Healthcare

Brexit: The Economics of International Disintegration 
1497 Francesco Caselli

Robot Arithmetic: Can New Technology

Alan Manning

Harm All Workers or the Average Worker?

1496 Nicholas Bloom

Are Ideas Getting Harder to Find?

Charles I Jones

John Van Reenen

Michael Webb

1495 Christian Krekel

Can Rising Instructional Time Crowd out Student Pro-Social Behaviour? Unintended Consequences of a German High School Reform

1494 Lorenzo Caliendo

Goods and Factor Market Integration: A

Luca David Opromolla

Fernando Parro

Quantitative Assessment of the EU

Alessandro Sforza

Enlargement

1493 Andrew E. Clark

Sarah Flèche

Warn N. Lekfuangfu

The Long-Lasting Effects of Family and Childhood on Adult Wellbeing: Evidence from British Cohort Data

1492 Daniel Paravisini

Veronica Rappoport

Philipp Schnabl

Specialization in Bank Lending: Evidence from Exporting Firms

1491 M.A. Clemens

The Labor Market Effects of Refugee Waves:

J. Hunt

Reconciling Conflicting Results

1490 V. Bhaskar

Robin Linacre

The Economic Functioning of Online Drug

Stephen Machin

Markets

The Centre for Economic Performance Publications Unit

Tel: +44 (0)207955 7673 Email info@cep.lse.ac.uk

Website: http://cep.lse.ac.uk Twitter: @CEP_LSE 